\title{
Biological Sister
}

National Cancer Institute

\section{Source}

National Cancer Institute. Biological Sister. NCI Thesaurus. Code C96586.

A female who shares with her sibling the genetic makeup inherited from one or both of their shared biological parents. 